\title{
Production and breeding performance of South African dairy herds
}

\author{
H.E. Theron ${ }^{\#}$ and B.E. Mostert \\ ARC-Animal Production Institute, Private Bag X2, Irene 0062, South Africa
}

\begin{abstract}
Comparisons between production and breeding potential of different feeding systems (Concentrates, Mixed and Pastures) in South Africa were made. Data of active cows participating in performance testing as at November 2007 were used. Holstein cows numbered 68280 in 254 herds and Jersey cows 51275 in 248 herds. Average milk production and lactation number were $8147 \pm 2260$ and $2.9 \pm 1.8$ for Holstein and 5347 \pm 1156 and $3.1 \pm 2.0$ for Jersey, respectively. Most Holstein and Jersey herds (53\%) were on Mixed rations, followed by Concentrates (28\%) and Pastures (19\%). Milk production was $9967 \pm 2022 ; 6996 \pm 1623$ and $7143 \pm 1549 \mathrm{~kg}$ for Holstein and $6385 \pm 1233 ; 5155 \pm 955$ and $4753 \pm 1022 \mathrm{~kg}$ for Jersey cows, respectively, for Concentrates, Mixed and Pasture systems. Most sires used were local (49\% of Holstein sires and 68\% of Jersey sires). Imported Holstein sires were mostly from USA (30\%) and The Netherlands (17\%), and foreign Jersey sires $(26 \%)$ were mostly from the USA. Farmers seemed to select the same sires on the different feeding regimes. Differences between feeding regimes were significant.
\end{abstract}

Keywords: Concentrates, pasture systems, sire selection

${ }^{\#}$ Corresponding author. E-mail: Helena@ arc.agric.za

\section{Introduction}

Production on dairy farms worldwide has changed significantly due to technological advances in milking systems, feeding methods, housing and biotechnology (Parsons et al., 2004). The total number of dairy farms and dairy cows are decreasing and farms tend to be larger with more cows per farm (Alvarez et al., 2008; Fulkerson et al., 2008). This is also evident in South Africa, as the total number of dairy herds decreased by $30 \%$ from 5347 in 2001 to 3727 in 2007, while the number of cows only decreased by $3 \%$ from 532000 to 515000 over the same period (ICAR, 2007). The average number of cows per herd has, however, more than doubled in the same period from 60 to 138, with production increasing from 3840 to $4590 \mathrm{~kg}$ per cow per lactation (ICAR, 2007). Because of the increased investment in milking facilities and housing, herd size often has to double or triple for an expansion project to be profitable (Parsons et al., 2004). However, some producers prefer a low cost production system that relies on pastures (Kearney et al., 2004; Parsons et al., 2004; Horan et al., 2006). Pastures as a form of low input dairy production is practiced in the United States (Parsons et al., 2004), Europe (Horan et al., 2006; Alvarez et al., 2008), Australia/New Zealand (Fulkerson et al., 2008; Bryant et al., 2007) and South Africa, where there is a shift in dairy herds towards the Tsitsikamma area in the Eastern Cape. Cows on pastures produce, on average, less milk than cows on concentrate rations (Berry et al., 2003; Boettcher et al., 2003; Kearney et al., 2004; Horan et al., 2006; Alvarez et al., 2008). If managed efficiently (Alvarez et al., 2008) the lower input costs of production on pastures are usually enough to offset lower production, due to less overhead, capital and feeding costs (Kearney et al., 2004; McCarthy et al., 2007).

There is, however, concern that the current artificial insemination (AI) sires that are selected based on daughters producing on concentrates, are not the best genotypes for use on pastures (Berry et al., 2003; Boettcher et al., 2003; Kearney et al., 2004; Horan et al., 2006; Bryant et al., 2007; Fulkerson et al., 2008). When bulls rank differently on pastures and concentrates, it is referred to as genotype by environment interaction, or GxE (Falconer \& Mackay, 1996). In breeding value estimation, if existing GxE interaction is not accounted for, breeding values might be biased and reduce effectiveness of selection (Calus et al., 2002). Results from the literature regarding GxE in dairy cattle vary from no differences to substantial differences (Berry et al., 2003; Boettcher et al., 2003; Kearney et al., 2004; Horan et al., 2006; Windig et al., 2006; McCarthy et al., 2007; Bryant et al., 2007; Fulkerson et al., 2008). The aim of the study was to compare the production and the origin of sires of cows on different South African production systems. 


\section{Material and Methods}

Data of Holstein and Jersey cows with milk production records were obtained from the INTERGIS database for cows participating in the National Dairy Animal Performance Testing Scheme (NDAPTS). Animals were classified as active (alive) during November 2007. Herds with at least 100 animals (cows, heifers and calves) were identified. Herds were located in one of five regions, viz. Western-Cape, EasternCape, Free State, Northern Provinces and KwaZulu-Natal. Herds were classified with the help of the regional officers of the NDAPTS, who worked closely with the farmers involved. Each herd's feeding system was classified as Concentrates, Pastures or Mixed (any amount of mixture of concentrates and pastures). Results presented in this study are for cows that were alive, had at least one milk production record and participated in the South African National Dairy Animal Performance Testing Scheme during November 2007. The traits available were cow identification number, herd number, location of herd, sire, dam, inbreeding coefficient, birth date, lactation number, milk $(\mathrm{kg})$, butterfat $(\mathrm{kg}$ and \%) and protein $(\mathrm{kg}$ and \%) production. Production and breeding potential in the different regions and feeding systems were compared using SAS (2006). Significance testing was done with Bonferroni (Dunn) t-tests. As AI is widely used, the origins of the sires of cows were also investigated. Sires and country of origin of sire were as recorded by breeders and captured with the relevant Breed Society or on the INTERGIS. Unknown sires were assumed to be local.

\section{Results and Discussion}

Cows were born between 1990 and 2005. There were slightly more Holstein (254) than Jersey herds (248), although there were more Holstein cows (68280) than Jersey cows (51275). Holstein herds were equally spread among the regions, while Jersey herds were concentrated in the Western- and Eastern-Cape (Table 1).

Table 1 Distribution of South African dairy cows and herds

\begin{tabular}{lrrrrrr}
\hline & \multicolumn{2}{c}{ Number of Holstein cows (herds) } & \multicolumn{2}{c}{ Number of Jersey cows (herds) } \\
Region & Concentrates & \multicolumn{1}{c}{ Pastures } & \multicolumn{1}{c}{ Mixed } & Concentrates & \multicolumn{1}{c}{ Pastures } & Mixed \\
\hline & & & & & & \\
W-Cape & $11525(27)$ & $0(0)$ & $4469(31)$ & $4150(18)$ & $4016(30)$ & $16944(78)$ \\
E-Cape & $213(1)$ & $0(0)$ & $14986(36)$ & $12(1)$ & $0(0)$ & $12707(42)$ \\
Free State & $4366(13)$ & $233(1)$ & $4156(39)$ & $1390(7)$ & $235(3)$ & $3576(21)$ \\
North & $8689(48)$ & $190(3)$ & $794(7)$ & $2510(16)$ & $0(0)$ & $1118(11)$ \\
KZN & $798(2)$ & $17003(45)$ & $858(1)$ & $2143(8)$ & $2474(13)$ & $0(0)$ \\
\hline Total & $25591(91)$ & $17426(49)$ & $25263(114)$ & $10205(50)$ & $6725(46)$ & $34345(152)$ \\
$\%$ & $37 \%(35 \%)$ & $26 \%(19 \%)$ & $37 \%(44 \%)$ & $20 \%(20)$ & $13 \%(19 \%)$ & $67 \%(61 \%)$ \\
\hline
\end{tabular}

KZN - KwaZulu-Natal

Most of the herds (Holstein and Jersey) were on Mixed rations. Herds in the Western and Eastern Cape tended to be on pastures for most of the year, but in the hot, dry summer months supplementary feed was given, and these herds were therefore classified as Mixed. Both Holstein and Jersey herds were mostly on Mixed rations, although there were slightly more Holstein cows on Concentrates than on Mixed rations (25591 and 25263, respectively). The Eastern Cape region had mostly Mixed rations, while KZN utilized mostly Pastures. Concentrates herds were mostly found in the Northern provinces.

Cows on Concentrates tended to be more inbred than cows on Pastures and on Mixed feeding for both breeds. Total average lactation numbers were slightly lower for South African Holstein (2.88) and Jersey cows (3.09) than for their American counterparts (2.94 and 3.24 respectively) (Hare et al., 2006). Average lactation number was lowest for cows on Concentrates and highest for cows on Pastures. As expected, production was highest for cows on Concentrates and lowest for cows on Pastures for Holsteins (Table 2) and Jerseys (Table 3). This can be ascribed to the inability of cows on grazing to consume sufficient 
metabolizable energy for high production due to intake constraints (MacDonald et al., 2007; Fulkerson et al., 2008). Protein production of cows on Mixed and Pastures did not differ significantly and butterfat percentage and protein percentage was highest for Holstein cows on Mixed rations (Table 3).

Table 2 Least Squares Mean ( \pm s.d.) inbreeding, lactation number and 300 day production of South African Holstein cows participating in the Dairy Cattle Improvement Scheme in 2007

\begin{tabular}{|c|c|c|c|c|c|c|c|}
\hline \multirow[b]{2}{*}{ Ration } & \multirow{2}{*}{$\begin{array}{c}\text { Average } \\
\text { inbreeding } \\
\text { coefficients }\end{array}$} & \multirow{2}{*}{$\begin{array}{c}\text { Average } \\
\text { lactation } \\
\text { number }\end{array}$} & \multicolumn{5}{|c|}{ Production } \\
\hline & & & $\begin{array}{c}\text { Milk } \\
(\mathrm{kg})\end{array}$ & $\begin{array}{c}\text { Butterfat } \\
(\mathrm{kg})\end{array}$ & $\begin{array}{c}\text { Protein } \\
(\mathrm{kg})\end{array}$ & $\begin{array}{c}\text { Butterfat } \\
\% \\
\end{array}$ & $\begin{array}{c}\text { Protein } \\
\%\end{array}$ \\
\hline Concentrates & $3.98^{\mathrm{a}} \pm 2.3$ & $2.50^{\mathrm{c}} \pm 1.5$ & $9967^{\mathrm{a}} \pm 2022$ & $378^{a} \pm 76$ & $318^{a} \pm 63$ & $3.81^{\mathrm{b}} \pm .33$ & $3.20^{\mathrm{c}} \pm .18$ \\
\hline Mixed & $3.02^{\mathrm{c}} \pm 2.4$ & $3.13^{\mathrm{a}} \pm 1.9$ & $6996^{c} \pm 1623$ & $270^{\mathrm{b}} \pm 57$ & $228^{\mathrm{b}} \pm 50$ & $3.90^{\mathrm{a}} \pm .35$ & $3.27^{\mathrm{a}} \pm .21$ \\
\hline Pastures & $3.46^{\mathrm{b}} \pm 2.3$ & $3.09^{b} \pm 1.9$ & $7143^{b} \pm 1549$ & $268^{c} \pm 54$ & $229^{\mathrm{b}} \pm 47$ & $3.78^{c} \pm .30$ & $3.21^{\mathrm{b}} \pm .19$ \\
\hline Total & $3.54 \pm 2.35$ & $2.88 \pm 1.8$ & $8147 \pm 2260$ & $310 \pm 83$ & $262 \pm 70$ & $3.84 \pm .33$ & $3.23 \pm .20$ \\
\hline
\end{tabular}

${ }^{a, b, c}$ Column means with different superscripts differ significantly at $\mathrm{P}<0.05$.

Table 3 Least Squares Mean ( \pm s.d.) inbreeding coefficient, lactation number and production of South African Jersey cows participating in the Dairy Cattle Improvement Scheme in 2007

\begin{tabular}{lccccccc}
\hline \multirow{2}{*}{ Ration } & $\begin{array}{c}\text { Mean } \\
\text { inbreeding } \\
\text { coefficient }\end{array}$ & $\begin{array}{c}\text { Average } \\
\text { lactation } \\
\text { number }\end{array}$ & $\begin{array}{c}\text { Milk } \\
(\mathrm{kg})\end{array}$ & $\begin{array}{c}\text { Butterfat } \\
(\mathrm{kg})\end{array}$ & $\begin{array}{c}\text { Protein } \\
(\mathrm{kg})\end{array}$ & $\begin{array}{c}\text { Butterfat } \\
\%\end{array}$ & $\begin{array}{c}\text { Protein } \\
\%\end{array}$ \\
\hline Concentrates & $4.24^{\mathrm{a}} \pm 3.1$ & $2.80^{\mathrm{c}} \pm 1.7$ & $6385^{\mathrm{a}} \pm 1233$ & $303^{\mathrm{a}} \pm 56$ & $238^{\mathrm{a}} \pm 45$ & $4.77^{\mathrm{a}} \pm .37$ & $3.74^{\mathrm{b}} \pm .23$ \\
Mixed & $3.13^{\mathrm{c}} \pm 3.0$ & $3.13^{\mathrm{b}} \pm 2.0$ & $5155^{\mathrm{b}} \pm 955$ & $242^{\mathrm{b}} \pm 45$ & $194^{\mathrm{b}} \pm 36$ & $4.71^{\mathrm{b}} \pm .39$ & $3.76^{\mathrm{a}} \pm .23$ \\
Pastures & $3.27^{\mathrm{b}} \pm 3.0$ & $3.29^{\mathrm{a}} \pm 2.1$ & $4754^{\mathrm{c}} \pm 1022$ & $221^{\mathrm{c}} \pm 45$ & $176^{\mathrm{c}} \pm 36$ & $4.67^{\mathrm{c}} \pm .39$ & $3.71^{\mathrm{c}} \pm .24$ \\
\hline Total & $3.44 \pm 3.08$ & $3.09 \pm 2.0$ & $5347 \pm 1156$ & $251 \pm 54$ & $200 \pm 43$ & $4.72 \pm .39$ & $3.75 \pm .23$
\end{tabular}

$\overline{\mathrm{a}, \mathrm{b}, \mathrm{c}}$ Column means with different superscripts differ significantly at $\mathrm{P}<0.05$.

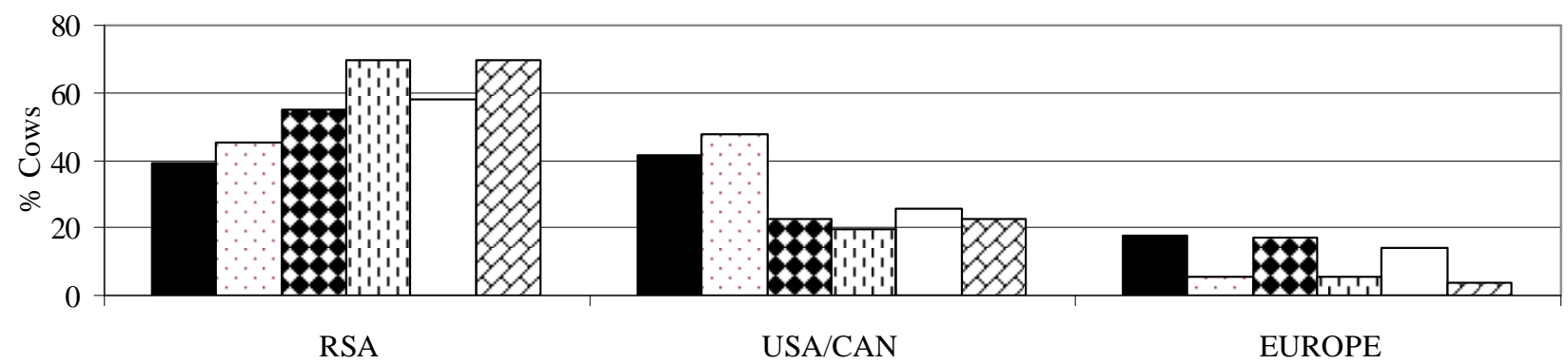

Conc. Holstein $\square$ Conc. Jersey $\square$ Mixed Holstein $\square$ Mixed Jersey $\square$ Pastures Holstein $\square$ Pastures Jersey

Figure 1 The origin of the sires of cows in milk recording in South Africa during November 2007.

The origin of the sires of the cows was also investigated. Half $(50 \%)$ of the Holstein cows had imported sires, mostly from the USA (25\%) and the Netherlands (13\%). Australian sires accounted for $0.8 \%$ on cows and $3 \%$ on heifers. Less than half the sires of Holstein cows (39\%) on Concentrates were local, they were mostly imported from the USA (34\%), the Netherlands (12\%), Canada (8\%) and Italy (4\%). Sires of cows on Mixed and Pastures were, however, mostly local (55\% and 58\%, respectively). Foreign sires for 
cows on mixed and pastures were mostly from the USA/Canada (23\% and $26 \%$, respectively) and the Netherlands (13\% and 14\%, respectively), as well as New Zealand/Australia (6\% and 2\%, respectively). Fulkerson et al. (2008) reported that over $80 \%$ of Australian Holstein genes were from the USA. South African Holstein will also have a high percentage of USA genes, as especially locally bred AI sires are mostly bred from USA genetics.

Close to $70 \%$ of Jersey cows have local sires, although there seems to be an increase in popularity of imported semen, as fewer heifers have local sires. Imported semen was mostly from the USA. As for Holstein, less than half the sires of Jersey cows $(45 \%)$ on Concentrates were local. Sires of Concentrates cows originating in the USA equaled the number of local sires. However, breeders of cows for Mixed and Pastures preferred local bulls $(70 \%)$. Foreign Jersey sires were from the USA/Canada, Denmark and New Zealand.

There does not seem to be a difference in popular Holstein sire selection between feeding regimes, as one bull was popular on all three regimes, and two bulls were on the top 5 list of both Concentrates and Pastures. The same Jersey sires also seemed to be popular on all three feeding regimes, with two sires common to all three regimes and the same four sires took the top four spots on both Mixed and Pastures.

It is generally accepted that effects of GxE on accuracy of sire rankings are not large enough to warrant a separate selection programme directed toward pasture production systems (Boettcher et al., 2003; Kearney et al., 2004; Bryant et al., 2007). Weigel et al. (1999) estimated that a separate sire proving programme for pasture production systems would require sampling of 600 to 700 bulls per year to achieve the same genetic progress as using sires based on a national programme for which results were genetically correlated by 0.90 . The practice of using sires proven from New Zealand or Ireland is questioned, due to small progeny testing programmes in these countries (Boettcher et al., 2003; Kearney et al., 2004; Fulkerson et al., 2008). This problem could be resolved by borderless international sire evaluations, where breeders can select bulls from different environments, rather than different countries (Boettcher et al., 2003; Zwald et al., 2003; Kearney et al., 2004).

\section{Conclusion}

Under South African conditions there were significant differences in production and longevity between cows on Concentrate, Mixed and Pasture feeding regimes, therefore indicating that GxE might exist and needs to be investigated. Although there were significant differences in production of both Holstein and Jersey cows on the different feeding regimes, breeders tended to select mostly the same top sires.

\section{Literature}

Alvarez, A., del Corral, J., Solis, D. \& Perez, J.A., 2008. Does intensification improve the economic efficiency of dairy farms? J. Dairy Sci. 91, 3693-3698.

Berry, D.P., Buckley, F., Dillon, P. Evans, R.D., Rath, M. \& Veerkamp, R.F., 2003. Estimation of genotype $\mathrm{x}$ environment interactions, in a grass-based system, for milk yield, body condition score, and body weight using random regression models. J. Dairy Sci. 83, 191-203.

Boettcher, P.J., Fatehi, J. \& Schultz, M.M., 2003. Genotype x environment interactions in conventional versus pasture-based dairies in Canada. J. Dairy Sci. 86, 383-389.

Bryant. J.R., Lopez-Villalobos, N., Pryce, J.E., Holmes, C.W., Johnson, D.L. \& Garrick, D.L., 2007. Environmental sensitivity in New Zealand dairy cattle. J. Dairy Sci. 90, 1538-1547.

Calus, P.L., Groen, A.F. \& De Jong, G., 2002. Genotype x environment interaction of protein yield in Dutch dairy cattle as quantified by different models. J. Dairy Sci. 85, 3115-3123.

Falconer, D.S. \& Mackay, T.F.C., 1996. Introduction to quantitative genetics. $4^{\text {th }}$ Edition. Longman Group, Essex, UK.

Fulkerson, W.J., Davison, T.M., Garcia, S.C., Hough, G., Goddard, M.E., Dobos, R. \& Blockey, M., 2008. Holstein-Friesian dairy cows under a predominantly grazing system: Interaction between genotype and environment. J. Dairy Sci. 91, 826-839.

Hare, E., Norman, H.D. \& Wright, J.R., 2006. Survival rates and productive herd life of dairy cattle in the United States. J. Dairy Sci. 89, 3713-3720. 
Horan, B., Faverdin, P., Delaby, L., Rath, M. \& Dillon, P., 2006. The effect of strain of Holstein-Friesian dairy cow and pasture-based system on grass intake and milk production. Animal Science 82, 435-444.

ICAR, 2007. The yearly cow milk enquiry. South Africa: National milk production. Published on www.icar.org.

Kearney, J.F., Schutz, M.M., Boettcher, P.J. \& Weigel, K.A., 2004a. Genotype x environment interaction for grazing versus confinement. 1. Production traits. J. Dairy Sci. 87, 501-509.

MacDonald, K.A., McNaughton, L.R., Verkerk, G.A., Penno, J.W., Burton, L.J., Berry, D.P., Gore, P.J.S., Lancaster, J.A.S. \& Holmes, C.W., 2007. A comparison of three strains of Holstein-Friesian cows grazed on pasture: growth, development and puberty. J. Dairy Sci. 90, 3993-4003.

McCarthy, S., Horan, B., Dillon, P., O'Connor, P. Rath, M. \& Shaloo, L. 2007. Economic comparison of divergent strains of Holstein-Friesian cows in various pasture-based production systems. J. Dairy Sci. 90, 1493-1505.

Parsons, R.L., Luloff, A.E. \& Hanson, G.D., 2004. Can we identify key characteristics associated with grazing-management dairy systems from survey data? J. Dairy Sci. 87, 2748-2760.

SAS, 2006. SAS Institute Inc., Cary, North Carolina, USA.

Windig, J.J., Calus, M.P.L., Beerda, B. \& Veerkamp, R.F., 2006. Genetic correlations between milk production and health and fertility depending on herd environment. J. Dairy Sci. 89, 1765-1775.

Weigel, K.A., Kriegl, T. \& Pohlman, A.L., 1999. Genetic analysis of dairy cattle production traits in a management intensive rotational grazing environment. J. Dairy Sci. 82, 191-195.

Zwald, N.R., Weigel, K.A., Fikse, W.F \& Rekaya, R., 2003. Identification of factors that cause genotype by environment interaction between herds of Holstein cattle in seventeen countries. J. Dairy Sci. 86, 1009-1018. 